\title{
Kinerja Perusahaan sebagai Pemediasi Pengaruh Penerapan Employee Stock Option Plan (ESOP) pada Nilai Perusahaan
}

\author{
Ni Ayu Wisma Dewi ${ }^{1}$ \\ Fakultas Ekonomi dan Bisnis \\ Universitas Udayana, Indonesia \\ Email: wisma264@gmail.com
}

\author{
Ida Bagus Putra Astika² \\ Fakultas Ekonomi dan Bisnis \\ Universitas Udayana, Indonesia
}

\begin{abstract}
ABSTRAK
Perseroan terbatas (PT) berlandaskan hubungan kerja sama anta ra pemilik dan pengelola yang diatur dalam suatu kontrak dan merupakan dasar dari teori keagenan dengan risiko terjadinya beda kepentingan yaitu munculnya konflik. Solusi untuk meminimalisir hal tersebut yaitu program kepemilikan saham oleh karyawan dengan strategi program opsi saham (Employee Stock Option Plan /ESOP). Tujuan penelitian ini adalah memperoleh bukti empiris pengaruhjumlah opsisaham yang dihibahkan pa da nilai perusahaan melalui kinerja perusahaan. Penelitian ini dilakukan pada perusahaan yang terdaftar di Bursa Efek Indonesia dan melakukan hibah ESOP tahun 2014-2018. Sampel yang diperoleh menggunakan purposive sampling adalah sebanyak 48 amatan. Teknik analisis data yang digunakan yaitu analisis jalur. Hasil penelitian menunjukkan bahwa jumlah opsi saham yang dihibahkan berpengaruh positif pada kinerja perusahaan, kin erja perusahaan berpengaruh positif pada nilai perusahaan, jumlah opsi saham yang dihibahkan berpengaruh positif pada nilai perusahaan, dan kinerja perusahaan memediasi hubungan a nta ra jumlah opsi saham yang dihibahkan dannilai perusahaan.
\end{abstract}

Kata Kunci: Employee Stock Option Plan; Kinerja Perusahaan; Nilai Perusahaan.

\section{Firm Performance Mediates The Impact of Employee Stock Option Plan (ESOP) on Firm Value}

\begin{abstract}
Limited liability company (Ltd) based on a contract cooperative relationship which is the basis of agency theorywith the risk of conflict. The solution to minimize is the employee stock ownership program with the Employee Stock Option Plan (ESOP) strategy. The purpose of this study is to obtain empirical evidence of the relationship of stock op tions granted's number to the firm value through firm performance. This research was conducted at companies listed in the BEI and conducted ESOP grants in 2014-2018. Samples obtained using purposive sampling were 48 observations. Data analysis technique used is path analysis. The results showed that the number of stock options granted had a positive effect on firm performance, firm performance had a positive effect on firm value, the number of shares options granted had a positive effect on firm value, and firm performance mediated the relationship between the number of shares op tions granted and firm value.
\end{abstract}

Keywords: $\quad$ Employee Stock Option Plan; Firm Performance; Firm Value.

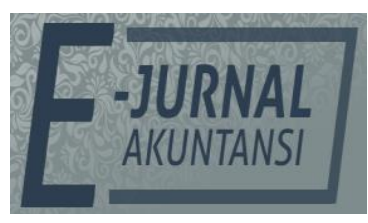

E-JA

e-Jurnal Akuntansi e-ISSN 2302-8556

Vol. 30 No. 4

Denpasar, April 2020

Hal. 993-1005

Artikel Masuk: 7 Januari 2020

Tanggal Diterima: 17 Februari 2020 


\section{PENDAHULUAN}

Perusahaan yang berbentuk perseroan terbatas (PT) di dalamnya terjalin hubungan kerja sama antara pemilik dan pengelola perusahaan yang diatur dalam suatu kontrak. Hubungan kerja sama ini disebut dengan hubungan keagenan yang merupakan dasar dari teori keagenan (agency theory). Teori keagenan menyatakan bahwa principal memberikan wewenang kepada agent untuk mengelola perusahaan dan mengambil keputusan atas nama principal, selanjutnya agent berkewajiban untuk melaporkan perkembangan perusahaan sebagai bentuk pertanggungjabawan (Watt \& Zimmerman, 1986). Pendelegasian wewenang dari pemilik kepada pengelola memiliki risiko terjadinya beda kepentingan seperti menimbulkan konflik (Jensen \& Meckling, 2012). Konflik yang muncul dalam hubungan keagenan dapat dikendalikan. Salah satu cara yang dapat dilakukan yaitu dengan program kepemilikan saham oleh karyawan (Employee Stock Ownership Program) dalam arti luas. Terdapat beber apa strategi atau pola yang dapat ditempuh agar karyawan memiliki saham perusahaan yaitu dengan pemberian saham dalam bentuk bonus, pemberian dengan cuma cuma dan pemberian melalui program opsi saham karyawan, serta lainnya (Astika, 2012).

Program opsi saham karyawan (Employee Stock Option Plan /ESOP) tidak mengikutsertakan seluruh karyawan perusahaan. Dalam program ini karyawan membeli saham perusahaan melalui penerbitan opsi saham dengan harga yang disepakati dimuka, biasanya saat pengumuman dan membayarnya pada saat opsi jatuh tempo dikemudian hari. Program ini menjadi menarik bagi kary awan karena pada saat mereka membayar, harga pasar saham perusahaan yang bersangkutan sangat mungkin lebih tinggi dari jumlah yang dibayarkan. Pelaksanaan ESOP dibagi menjadi tiga tahapan (event) yaitu tahap pengumuman, tahap hibah opsi dan tahap eksekusi saham dengan waktu pergeseran setiap tahap rata-rata 3 tahun (Astika, 2012). Dalam penelitian ini, yang akan menjadi fokus penelitian adalah tahap hibah opsi saham dengan pengukuran yaitu proporsi opsi saham karena jumlah opsi saham merupakan bagian penting dari ESOP yang menggambarkan jumlah saham yang akan dimiliki karyawan di masa yang akan dating.

Program opsi saham ini dapat menciptakan rasa memiliki (sense of belonging) karyawan terhadap perusahaan (Herdinata, 2012). Apabila telah timbul rasa memiliki karyawan terhadap perusahaan, maka karyawan diharapkan dapat lebih mengutamakan kepentingan perusahaan untuk tujuan bersama. Selain itu dengan adanya hibah opsi saham, karyawan juga akan termotivasi untuk meningkatkan kinerjanya karena karyawan tersebut memiliki tanggung jawab sebagai pemilik perusahaan. Peningkatan kinerja karyawan tentunya selajan dengan meningkatnya kinerja perusahaan dan nantinya akan berdampak pada peningkatan nilai perusahaan tersebut.

Pada umumnya kinerja suatu perusahaan dinilai dari kinerja keuangan karena menggambarkan kondisi keuangannya yang dianalisis dengan alat-alat analisis keuangan, sehingga dapat diketahui mengenai baik buruknya keadaan keuangan suatu perusahaan yang mencerminkan prestasi kerja dalam periode tertentu. Dengan adanya opsi saham yang dihibahkan perusahaan diharapkan kinerja karyawan lebih efektif dan efisien sehingga mampu menghasilkan kinerja 
perusahaan yang baik yang dicerminkan dengan keberhasilan meningkatkan produktivitas perusahaan dengan tingkat perolehan laba (profit) yang tinggi. Dengan demikian, maka dalam penelitian ini kinerja perusahaan diukur dengan menggunakan salah satu rasio profitabilitas yaitu Net Profit Margin (NPM) atau margin laba bersih karena perusahaan yang menghasilkan laba bersih secara maksimal dapat dilihat menggunakan rasio ini. Rasio NPM yang semakin tinggi menggambarkan semakin efisien kinerja operasional perusahaan dalam memperoleh laba yang tinggi, sehingga akan meningkatkan kepercayaan investor.

Indikator yang sering digunakan untuk menilai kinerja perusahaan ialah tingkat pengembalian (return) terhadap pemilik dan nilai perusahaan (Hutnaleontina, 2016). Peningkatan kinerja yang berpeluang terjadi karena pelaksanaan ESOP akan berpengaruh pada nilai perusahaan. Fama (1978) menyatakan bahwa nilai perusahaan akan tercermin dari harga saham. Pada penelitian ini, indikator yang digunakan untuk mengukur nilai perusahaan adalah Price to Book Value (PBV). Menurut Murhadi (2009) keunggulan dari penggunaan PBV dalam mengukur nilai perusahaan yaitu, PBV sifatnya relatif stabil dalam mewakili nilai harga wajar saham, karena dihitung berdasarkan ekuitas perusahaan dimana saat perusahaan mampu menciptakan laba maka nilainya juga akan ikut meningkat. Kedua, PBV memberikan standar akuntansi yang konsisten untuk semua perusahaan sehingga dapat dibandingkan dengan antar perusahaan yang akhirnya dapat memberikan sinyal apakah nilai perusahaan tersebut overvalued (di atas) atau undervalued (di bawah). Ketiga, perusahaan dengan earning negative yang tidak dapat dinilai dengan Price Earning Ratio (PER) dapat dievaluasi dengan Price to Book Value (PBV).

Penelitian mengenai ESOP, kinerja perusahaan, dan nilai perusahaan sudah pernah diteliti oleh peneliti-peneliti sebelumnya dan memperoleh hasil yang berbeda-beda. Zhu et al., (2013) dalam penelitiannya membandingkan kinerja perusahaan Huawei (melaksanakan ESOP) dan ZTE (tidak melaksanakan ESOP) memperoleh hasil bahwa ESOP memberikan dampak yang positif terhadap produktivitas dengan peningkatan laba bersih (net profit) perusahaan Huawei. Hal ini sejalan dengan penelitian yang dilakukan oleh Rathore \& Shukla (2015), Ngambi dan Oloume (2013), Iqbal dan Hamid (2000) dan juga Han dan Shen (2007) serta Pugh et al. (2000) yang menyatakan bahwa ESOP berpengaruh positif terhadap kinerja perusahaan. Namun penelitian Setiawan (2017) memperoleh hasil sebaliknya yaitu belum ditemukan pengaruh signifikan kinerja perusahaan yang diproksikan dengan Net Profit Margin (NPM) dengan adanya pelaksanaan ESOP. Begitu pula penelitian dari Poornima et al. (2015), Kalra dan Bagga (2017) dan Bacha et al. (2009) serta Blasi et al. (2016) yang menunjukkan bahwa ESOP tidak mampu meningkatkan kinerja perusahaan.

Pengaruh ESOP terhadap nilai perusahaan dalam penelitian Aribawa (2016) dan Letlora (2012) memperoleh hasil bahwa nilai perusahaan setelah perusahaan mengadopsi ESOP berpengaruh positif oleh karena adanya respons dan penilaian yang baik dari investor kepada perusahaan. Begitu pula hasil dari penelitian Mardiantari (2015) yaitu dengan pelaksanaan ESOP menimbulkan ketertarikan berinvestasinya investor pada perusahaan yang mempengaruhi peningkatan nilai perusahaan karena terjadi peningkatan pada harga saham 
perusahaan yang ditandai dengan peningkatan PBV. Namun tidak sejalan dengan penelitian Qureyta (2016) yang membuktikan bahwa kinerja pasar perusahaan yang diproksikan dengan PER dan PBV setelah penerapan ESOP tidak lebih baik daripada tahun sebelum penerapan ESOP.

Penerapan ESOP menunjukkan karyawan diberikan kesempatan untuk membeli sebagian saham perusahaan dalam suatu periode tertentu pada tingkat harga yang telah ditentukan pada saat opsi diberikan. Nilai suatu opsi saham bagi karyawan sifatnya terkait pada kinerja perusahaan di masa yang akan datang. Dengan kata lain, ESOP merupakan salah satu strategi yang bertujuan untuk mengikat sekaligus memberi apresiasi pada karyawan dalam jangka panjang.. Salah satu indikator perusahaan dengan kinerja yang baik adalah mampu terus meningkatkan profitabilitas perusahan dari masa ke masa dengan adanya perolehan laba bersih perusahaan yang tinggi dan tepat. Untuk menilai bagaimana perusahaan dapat menghasilkan laba bersih secara maksimal dapat dilihat menggunakan rasio NPM. Dengan demikian, maka dengan hibah opsi saham pada ESOP diharapkan dapat meningkatkan kinerja perusahaan yang diproksikan dengan peningkatan rasio NPM.

Penelitian sebelumnya yang dilakukan oleh Zhu et al., (2013) dalam penelitiannya memperoleh hasil bahwa ESOP memberikan dampak yang posit if terhadap produktivitas dengan peningkatan laba bersih (net profit) perusahaan yang menerapkan ESOP dibandingkan dengan yang tidak menerapkannya. Hutnaleontina (2016) menunjukkan bahwa semakin tinggi proporsi saham yang dihibahkan, maka semakin tinggi pula kinerja keuangan perusahaan. Hal ini sejalan dengan penelitian yang dilakukan oleh Fang et al. (2015), Rathore dan Shukla (2015) serta Ricci (2018) menyatakan bahwa ESOP terbukti ber pengaruh positif dalam meningkatkan kinerja perusahaan. Berdasarkan uraian tersebut, maka rumusan hipotesis dalam penelitian ini yaitu :

$\mathrm{H}_{1}$ : Jumlah opsi saham yang dihibahkan berpengaruh positif pada kinerja perusahaan.

Umumnya kinerja suatu perusahaan dinilai dari kinerja keuangan karena menggambarkan kondisi keuangan suatu perusahaan. Perusahaan yang memperoleh keuntungan maksimum adalah perusahaan yang dapat mengelola kinerja perusahaannya dengan baik. Kinerja keuangan yang baik tersebut dicerminkan dengan keberhasilan meningkatkan produktivitas perusahaan dengan tingkat perolehan laba (profit) yang tinggi. Untuk mengetahui perusahaan yang menghasilkan laba bersih secara maksimal dapat dilihat menggunakan rasio Net Profit Margin (NPM), dengan adanya peningkatan NPM maka dapat menjadi sinyal bagi investor untuk menanamkan modalnya pada perusahaan sehingga nilai perusahaan akan meningkat yang dinilai dengan rasio Price to Book Value (PBV).

Penelitian sebelumnya yang dilakukan oleh Apsari (2015) memperoleh hasil bahwa investor akan menanamkan modalnya pada perusaahan dengan tingkat keuntungan dari penjualan yang tinggi yang dinilai dari tingkat NPM, sehingga harga saham akan naik dan semakin meningkatkan nilai PBV. Hal serupa juga terdapat pada hasil penelitian Haqqi et al., (2017) dimana NPM berpengaruh secara simultan dan signifikan terhadap nilai perusahaan. Begitu pula hasil penelitian dari Wahyu \& Mahfud (2018) yang menyatakan bahwa 
peningkatan Net Profit Margin (NPM) akan diikuti oleh peningkatan Price to Book Value (PBV). Berdasarkan uraian tersebut, maka rumusan hipotesis dalam penelitian ini yaitu :

$\mathrm{H}_{2}$ : Kinerja perusahaan berpengaruh positif pada nilai perusahaan.

Nilai perusahaan yang tinggi sangat berarti bagi perusahaan karena menunjukkan tingginya kemakmuran pemegang saham dan menjanjikan prospek perusahaan di masa depan. Sesuai dengan konsep dari teori sinyal (signal theory) yang diungkapkan oleh Scott \& Brigham (2008) dimana karyawan termotivasi dalam bekerja karena adanya rasa memiliki melalui kepemilikan saham perusahaan dengan diterapkannya program ESOP. Kemudian peningkatan nilai perusahaan akan dipandang oleh investor sebagai akibat adanya hibah opsi saham pada ESOP. Sehingga, direaksi positif oleh investor karena dianggap sebagai kabar baik (good news) ketika perusahaan mengumumkan ESOP.

Penelitian dari Mardiantari (2015) menyebutkan bahwa pelaksanaan ESOP yang berjalan dengan efisien berakibat pada tingginya profitabilitas perusahaan yang menandakan baiknya prospek perusahaan. Prospek perusahaan yang baik akan menimbulkan ketertarikan berinvestasinya investor pada perusahaan yang mempengaruhi peningkatan nilai perusahaan karena terjadi peningkatan pada harga saham perusahaan. Hal ini mendukung hasil penelitian Letlora (2012) dimana penerapan ESOP dalam suatu perusahaan ditanggapi positif melalui perubahan harga pasar saham. Begitu pula dengan penelitian yang dilakukan oleh Aribawa (2016) yang menyatakan bahwa ESOP berpengaruh terhadap EVA yang merupakan tolak ukur dari nilai perusahaaan. Sehingga, berdasarkan uraian tersebut, maka rumusan hipotesis yang dapat diajukan dalam penelitian ini:

$\mathrm{H}_{3}$ : Jumlah opsi saham yang dihibahkan berpengaruh positif pada nilai perusahaan.

ESOP merupakan penghargaan yang diberikan kepada manager berupa opsi saham untuk dapat membeli saham perusahaan. Opsi atau pilihan saham ini diberikan sebagai bentuk motivasi kepada manager untuk dapat meningkatkan kinerja perusahaan. Insentif berupa hibah opsi saham dalam pelaksanaan ESOP diharapkan dapat meningkatkan nilai perusahaan melalui peningkatan kinerja karena fenomena kepemilikan saham oleh para eksekutif entitas bisnis merupakan salah satu bentuk strategi yang ditetapkan oleh pemilik perusahaan dengan tujuan mengikat karyawan potensial agar meningkatkan kinerja perusahaan sehingga akan berdampak pada peningkatan nilai perusahaan tersebut.

ESOP merupakan salah satu dari program manajemen sumber daya manusia berupa program kepemilikan saham perusahaan oleh karyawan di tempat karyawan tersebut bekerja yang diharapkan dapat mengurangi masalah keagenan dan meningkatkan nilai perusahaan melalui peningkatan kinerja perusahaan (Bapepam, 2002). Hal ini sejalan dengan penelitian Dharmala (2019), Hutnaleontina (2016) dan Mardiantari (2015) yang memperoleh hasil bahwa jumlah saham yang dihibahkan berpengaruh pada nilai perusahaan melalui kinerja keuangan. Semakin banyak jumlah saham yang dihibahkan kepada karyawan maka semakin tinggi pula kinerja keuangan perusahaan yang mana 
hal ini akan memberikan sinyal positif bagi pasar dan harga sahampun meningkat sehingga memiliki potensi untuk meningkatkan nilai perusahaan. Dengan demikian, rumusan hipotesis dalam penelitian ini yaitu :

$\mathrm{H}_{4}$ : Kinerja perusahaan memediasi hubungan antara jumlah opsi saham yang dihibahkan dan nilai perusahaan.

\section{METODE PENELITIAN}

Penelitian ini dilakukan pada perusahaan yang menerapkan ESOP dan terdaf tar di Bursa Efek Indonesia (BEI) pada tahun 2014-2018 yang diakses resmi di situs Bursa Efek Indonesia (www.idx.co.id) dan situs resmi perusahaan yang bersangkutan. Variabel terikat dalam penelitian ini adalah nilai perusahaan (Y). Variabel bebas dalam penelitian ini yaitu hibah opsi saham $\left(X_{1}\right)$. Variabel mediasi dalam penelitian ini adalah kinerja perusahaan $\left(X_{2}\right)$.

Variabel nilai perusahaan diukur dengan menggunakan Price to Book Value (PBV). Rasio PBV dihitung menggunakan rumus :

PBV = Nilai Buku Per Lembar Saham

Variabel hibah opsi saham akan diproksikan dengan proporsi opsi saham yang dihibahkan. Proporsi opsi saham dapat dihitung dengan rumus sebagai berikut. Jumlah opsi saham yang dihibahkan

Proporsi Opsi Saham $=$ Keseluruhan jumlah saham yang

Varibel kinerja perusahaan akan diproksikan dengan Net Profit Margin (NPM).

Rasio NPM dapat dirumuskan sebagai berikut.

Net Profit Margin (NPM) $=\frac{\text { Laba Bersih Setelah Pajak }}{\text { Penjualan }}$

Populasi dalam penelitian ini adalah seluruh perusahaan publik yang terdaftar di Bursa Efek Indonesia (BEI) dengan periode penelitian yang digunakan adalah dari tahun 2014 - 2018. Sampel pada penelitian ini adalah perusahaan yang terdaftar di Bursa Efek Indonesia (BEI) yang menerapkan ESOP pada tahun 20142018 yang sesuai dengan kriteria pemilihan sampel pada penelitian ini. Perusahaan yang menjadi sampel dalam penelitian ini yaitu sebanyak 17 perusahaan dengan 48 pengamatan.

Teknik analisis data yang digunakan untuk menyelesaikan masalah-masalah dalam penelitian ini adalah analisis jalur (path analysis) yang bertujuan memperoleh gambaran yang menyeluruh mengenai pengaruh ESOP dengan kinerja perusahaan sebagai pemediasi terhadap nilai perusahaan. Adapun persamaan diagram jalur pada penelitian ini yaitu :

Substruktur 1

$\mathrm{X}_{2}=\mathrm{aX}_{1}+\mathrm{e}_{1}$

Substruktur 2

$\mathrm{Y}=\mathrm{bX}_{1}+\mathrm{cX}_{2}+\mathrm{e}_{2}$

Keterangan:

$X_{1}=$ Hibah Opsi Saham

$\mathrm{X}_{2} \quad=$ Kinerja Perusahaan

$\mathrm{Y}=$ Nilai Perusahaan

$\mathrm{a}, \mathrm{b}, \mathrm{c}=$ Standardisasi Koefisien Regresi 
$\mathrm{e}_{1}, \mathrm{e}_{2}=$ error

\section{HASIL DAN PEMBAHASAN}

Pengujian statistik deskriptif digunakan untuk menganalisis data dengan memberikan gambaran atau deskripsi mengenai karakteristik variabel penelitian, yaitu penjelasan mengenai nilai maksimum, nilai minimum, nilai rata-rata (mean) dan nilai standar deviasi. Hasil dari pengujian statistik deskriptif dalam penelitian ini disajikan pada Tabel 1 sebagai berikut.

Tabel 1. Hasil Uji Statistik Deskriptif

\begin{tabular}{lccccc}
\hline & $\mathrm{N}$ & Minimum & Maximum & Mean & Std. Deviation \\
\hline PROPORSIOPSI & 48 & 0,0015 & 0,0600 & 0,010289 & 0,0098394 \\
SAHAM & & & & & \\
NPM & 48 & $-0,0482$ & 0,1721 & 0,056110 & 0,0519709 \\
PBV & 48 & 0,0018 & 0,0406 & 0,014244 & 0,0099287 \\
Valid N (listwise) & 48 & & & & \\
\hline
\end{tabular}

Sumber: Data Penelitian, 2019

Statistik deskriptif pada Tabel 1. menunjukkan bahwa jumlah observasi (N) sebanyak 48, dengan penjelasan untuk masing-masing variabel penelitian adalah sebagai berikut. Hibah Opsi Saham pada $\operatorname{ESOP}\left(\mathrm{X}_{1}\right)$ dalam penelitian ini diukur dengan proporsi opsi saham memiliki nilai maksimum sebesar 0,0600 dan nilai minimumnya sebesar 0,0015 . Nilai rata-rata (mean) dari proporsi opsi saham sebesar 0,0102892 dengan standar deviasi 0,0098394. Hal ini menunjukkan hasil yang cukup baik karena proporsi opsi saham memiliki fluktuasi yang kecil dan penyebaran data dengan hasil yang normal dan tidak menyebabkan bias dengan standar deviasi lebih kecil dibandingkan nilai rata-rata (mean).

Kinerja perusahaan $\left(\mathrm{X}_{2}\right)$ dalam penelitian ini diukur dengan Net Profit Margin (NPM) memiliki nilai maksimum sebesar 0,1721 dan nilai minimumnya sebesar -0,0482. Nilai rata-rata (mean) dari NPM sebesar 0,056110 dengan standar deviasi 0,0519709. Hal ini menunjukkan hasil yang cukup baik karena kinerja perusahaan memiliki fluktuasi yang kecil dan penyebaran data dengan hasil yang normal dan tidak menyebabkan bias dengan standar deviasi lebih kecil dibandingkan nilai rata-rata (mean).

Nilai perusahaan (Y) dalam penelitian ini diukur dengan Price to Book Value (PBV) memiliki nilai maksimum sebesar 0,0406 dan nilai minimumnya sebesar 0,0018 . Nilai rata-rata (mean) dari PBV sebesar 0,014244 dengan standar deviasi 0,0099287 . Hal ini menunjukkan hasil yang cukup baik karena nilai perusahaan memiliki fluktuasi yang kecil dan penyebaran data dengan hasil yang normal dan tidak menyebabkan bias dengan standar deviasi lebih kecil dibandingkan nilai rata-rata (mean).

Pengujian data dalam penelitian ini menggunakan teknik analisis jalur (path analysis). Menyusun model diagram jalur yang dapat dinyatakan dalam bentuk persamaan, sehingga membentuk sistem persamaan sebagai berikut.

Substruktur 1

$\mathrm{X}_{2}=\mathrm{aX} \mathrm{X}_{1}+\mathrm{e}_{1}$

Substruktur 2

$\mathrm{Y}=\mathrm{bX} \mathrm{X}_{1}+\mathrm{cX_{2 }}+\mathrm{e}_{2}$ 
Hubungan antar variabel adalah linier merupakan dasar pemeriksaan asumsi dalam analisis jalur. hubungan linier atau tanpa adanya hubungan dua arah merupakan syarat model yang telah dibuat. Berdasarkan model diagram jalur ditunjukkan bahwa hubungan antara variabel adalah linier.

Tabel 2. Hasil Uji Analisis Jalur Substruktur 1

\begin{tabular}{|c|c|c|c|c|c|}
\hline \multirow[t]{2}{*}{$\overline{\text { Model }}$} & \multicolumn{2}{|c|}{$\begin{array}{l}\text { Unstandardized } \\
\text { Coefficients }\end{array}$} & \multirow{2}{*}{$\begin{array}{l}\text { Standardized } \\
\text { Coefficients } \\
\text { Beta }\end{array}$} & \multirow[b]{2}{*}{$\mathrm{t}$} & \multirow[b]{2}{*}{ Sig. } \\
\hline & $\mathrm{B}$ & Std. Error & & & \\
\hline (Constant) & 0,011 & 0,139 & & 0,082 & 0,935 \\
\hline PROPORSIOPSI & 0,422 & 0,146 & 0,393 & 2,897 & 0,006 \\
\hline SAHAM & & & & & \\
\hline RSquare & 0,154 & & & & \\
\hline Adjusted R Square & 0,136 & & & & \\
\hline F Statistik & 8,393 & & & & \\
\hline SignifikansiUji F & 0,006 & & & & \\
\hline
\end{tabular}

Sumber: Data Penelitian, 2019

Berdasarkan hasil analisis jalur substruktur 1 seperti yang disajikan pada

Tabel 2. maka dapat dibuat persamaan struktural sebagai berikut :

$$
\begin{gathered}
\mathrm{X}_{2}=\mathrm{a} \mathrm{X}_{1}+\mathrm{e}_{1} \\
\mathrm{X}_{2}=0,422 \mathrm{X}_{1}+\mathrm{e}_{1}
\end{gathered}
$$

Nilai koefisien regresi variabel kinerja lingkungan bernilai positif dengan nilai signifikansi uji $\mathrm{t}<0,05$. Hal ini menunjukkan bahwa variabel hibah opsi saham memiliki pengaruh positif yang signifikan terhadap variabel kinerja perusahaan. Besarnya pengaruh variabel bebas terhadap variabel terikat yang ditunjukkan oleh nilai determinasi total (Adjusted $R$ Square) sebesar 0,136 mempunyai arti bahwa sebesar $13,6 \%$ variasi pengungkapan lingkungan dipengaruhi oleh variasi kinerja lingkungan, sedangkan sisanya yaitu sebesar 86,4\% dijelaskan oleh faktor lain yang tidak dimasukkan ke dalam model.

\begin{tabular}{|c|c|c|c|c|c|}
\hline \multirow[t]{2}{*}{ Model } & \multicolumn{2}{|c|}{$\begin{array}{l}\text { Unstandardized } \\
\text { Coefficients }\end{array}$} & \multirow{2}{*}{$\begin{array}{c}\begin{array}{c}\text { Standardized } \\
\text { Coefficients }\end{array} \\
\text { Beta }\end{array}$} & \multirow[b]{2}{*}{$\mathrm{t}$} & \multirow[b]{2}{*}{ Sig. } \\
\hline & $\mathrm{B}$ & Std. Error & & & \\
\hline (Constant) & 0,178 & 0,138 & & 1,287 & 0,205 \\
\hline PROPORSIOPSI & 0,422 & 0,158 & 0,361 & 2,677 & 0,010 \\
\hline SAHAM & & & & & \\
\hline NPM & 0,332 & 0,107 & 0,305 & 2,261 & 0,029 \\
\hline RSquare & 0,309 & & & & \\
\hline Adjusted R Square & 0,278 & & & & \\
\hline F Statistik & 10,071 & & & & \\
\hline SignifikansiUji F & 0,000 & & & & \\
\hline
\end{tabular}

Tabel 3. Hasil Uji Analisis Jalur Substruktur 2

Sumber: Data Penelitian, 2019

Berdasarkan hasil analisis jalur substruktur 2 seperti yang disajikan pada Tabel 3. maka dapat dibuat persamaan struktural sebagai berikut.

$$
\begin{gathered}
Y=b X 1+c X 2+e_{2} \\
Y=0,422 X 1+0,332 X 2+e_{2}
\end{gathered}
$$

Nilai signifikansi masing-masing variabel bebas $<0,050$. Hal ini menunjukkan bahwa semua variabel bebas memiliki pengaruh yang signifikan terhadap variabel terikat. Besarnya pengaruh variabel bebas terhadap variabel 
terikat yang ditunjukkan oleh nilai determinasi total (Adjusted $R$ Square) sebesar 0,278 mempunyai arti bahwa sebesar $27,8 \%$ variasi nilai perusahaan dipengaruhi oleh hibah opsi saham dan kinerja perusahaan, sedangkan sisanya sebesar 72,2\% dijelaskan oleh faktor lain yang tidak dimasukkan ke dalam model.

Berdasarkan model substruktur 1 dan substruktur 2, maka da pat disusun model diagram jalur akhir. Sebelum menyusun model diagram jalur akhir, terlebih dahulu dihitung nilai standar eror sebagai berikut.

$$
\begin{aligned}
& \mathrm{Pe}_{\mathrm{i}}=\sqrt{1-\mathrm{R}_{\mathrm{i}}{ }^{2}} \\
& \mathrm{Pe}_{1}=\sqrt{1-R_{1}{ }^{2}}=\sqrt{1-0,154}=0,920 \\
& \mathrm{Pe}_{2}=\sqrt{1-R_{2}{ }^{2}}=\sqrt{1-0,309}=0,831
\end{aligned}
$$

Berdasarkan perhitungan pengaruh error $\left(\mathrm{Pe}_{\mathrm{i}}\right)$, didapatkan hasil pengaruh error $\left(\mathrm{Pe}_{1}\right)$ sebesar 0,920 dan pengaruh error $\left(\mathrm{Pe}_{2}\right)$ sebesar 0,831 . Hasil koefisien determinasi total adalah sebagai berikut:

$$
\begin{aligned}
\mathrm{R}^{2} \mathrm{~m} & =1-\left(\mathrm{Pe}_{1}\right)^{2}\left(\mathrm{Pe}_{2}\right)^{2} \\
& =1-(0,920)^{2}(0,831)^{2} \\
& =1-(0,846)(0,691) \\
& =0,415
\end{aligned}
$$

Nilai determinasi total sebesar 0,415 mempunyai arti bahwa sebesar 41,5\% variasi nilai perusahaan yang melakukan hibah ESOP dipengaruhi oleh variasi hibah opsi saham dan kinerja perusahaan, sedangkan sisanya sebesar 58,5\% djelaskan oleh faktor lain yang tidak dimasukkan ke dalam model.

Apabila disajikan dalam bentuk model jalur, maka nilai koefisien jalur d an standar errornya akan tampak pada Gambar 1. sebagai berikut.

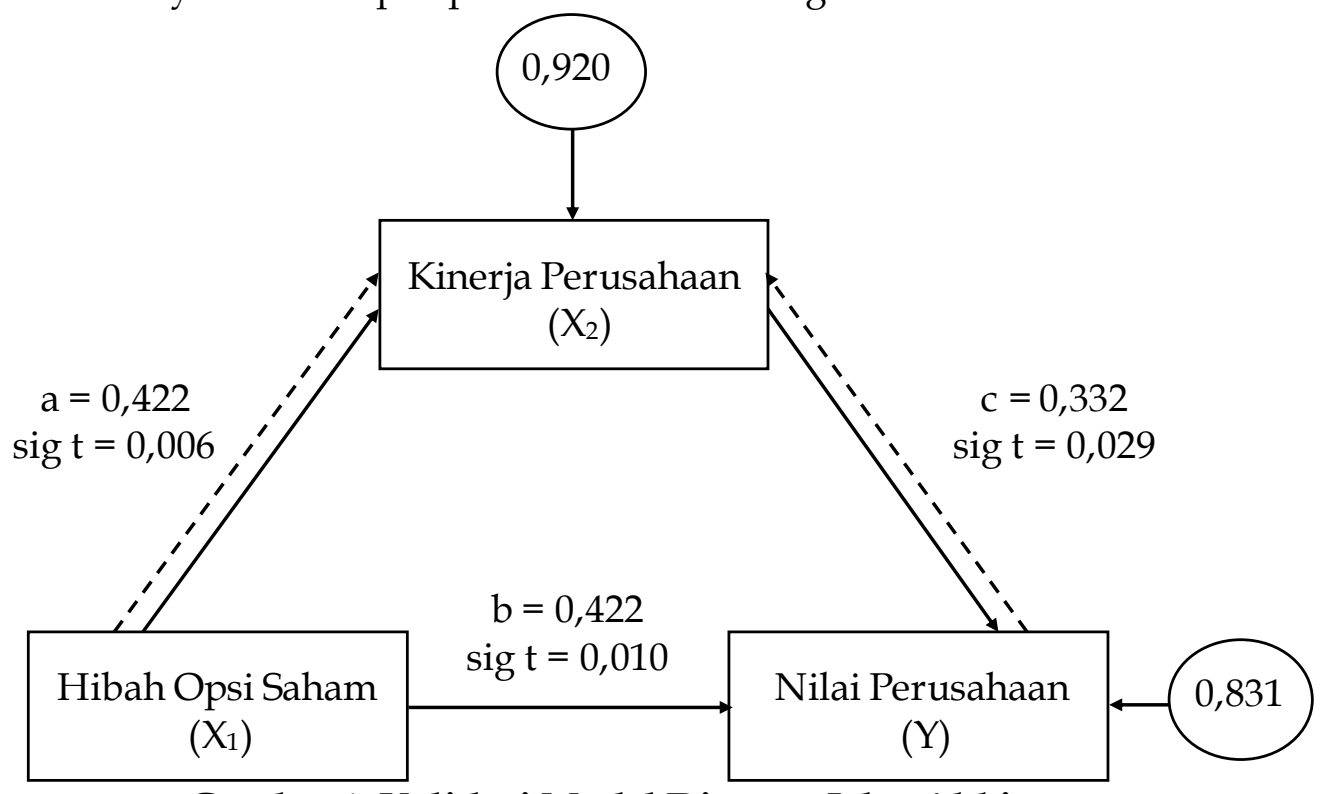

Gambar 1. Validasi Model Diagram Jalur Akhir

Sumber: Data Penelitian, 2019

Berdasarkan validasi model diagram jalur akhir pada Gambar 1. maka dapat dihitung besarnya pengaruh langsung dan pengaruh tidak langsung ser ta 
pengaruh total antar variabel. Perhitungan pengaruh antar variabel dirangkum dalam Tabel 4. sebagai berikut.

Tabel 4. Pengaruh Langsung dan Pengaruh Tidak Langsung serta Pengaruh Total Variabel Penelitian

\begin{tabular}{cccc}
\hline Pengaruh Variabel & $\begin{array}{c}\text { Pengaruh } \\
\text { Langsung } \\
(\mathrm{b})\end{array}$ & $\begin{array}{c}\text { Pengaruh Tidak Langsung } \\
\text { melalui Kinerja Perusahaan } \\
(\mathrm{a} \times \mathrm{c})\end{array}$ & $\begin{array}{c}\text { Pengaruh } \\
\text { Total } \\
(\mathrm{b}+(\mathrm{a} \times \mathrm{c})\end{array}$ \\
\hline $\mathrm{X}_{1} \rightarrow \mathrm{X}_{2}$ & 0,422 & - & 0,422 \\
$\mathrm{X}_{1} \rightarrow \mathrm{Y}$ & 0,422 & 0,140 & 0,562 \\
$\mathrm{X}_{2} \rightarrow \mathrm{Y}$ & 0,332 & - & 0,332 \\
\hline
\end{tabular}

Sumber: Data Penelitian, 2019

Tabel 4. menunjukkan bahwa pengaruh langsung hibah opsi saham terhadap kinerja perusahaan adalah sebesar 0,422. Pengaruh langsung hibah opsi saham terhadap nilai perusahaan sebesar 0,422. Pengaruh langsung kinerja perusahaan terhadap nilai perusahaan sebesar 0,332 . Hal ini berarti bahwa variabel nilai perusahaan lebih besar dipengaruhi oleh hibah opsi saham daripada kinerja perusahaan.

Uji Sobel merupakan alat analisis untuk menguji signifikansi dari hubungan tidak langsung antara variabel independen dengan variabel dependen yang dimediasi oleh variabel mediator. Untuk menguji signifikansi pengaruh tidak langsung maka nilai $\mathrm{z}$ dari koefisien $\mathrm{ab}$ dihitung dengan rumus sebagai berikut:

$$
\begin{aligned}
& Z=\frac{(0,422)(0,332)}{\sqrt{(0,332)^{2}(0,146)^{2}+(0,422)^{2}(0,107)^{2}+(0,146)^{2}(0,107)^{2}}} \\
& Z=\frac{0,140104}{0,068062}=2,0585
\end{aligned}
$$

Oleh karena $Z$ hitung sebesar 2,0585 > 1,96. Artinya kinerja perusahaan $\left(X_{2}\right)$ merupakan variabel yang memediasi jumlah opsi saham yang dihibahkan $\left(X_{1}\right)$ terhadap nilai perusahaan $(Y)$ atau dengan kata lain jumlah opsi saham yang dihibahkan berpengaruh secara tidak langsung terhadap nilai perusahaan melalui kinerja perusahaan.

Hipotesis pertama $\left(\mathrm{H}_{1}\right)$ dalam penelitian ini menyatakan bahwa jumlah opsi saham yang dihibahkan berpengaruh positif pada kinerja perusahaan. Berdasarkan hasil analisis jalur yang telah ditunjukkan pada Tabel 2. menunjukkan bahwa koefisien regresi standar sebesar 0,422 dengan tingkat signifikansi sebesar 0.006 lebih kecil dari 0.05. Hasil ini berarti $\mathrm{H}_{0}$ ditolak dan $\mathrm{H}_{1}$ diterima, sehingga dapat disimpulkan bahwa jumlah opsi saham yang dihibahkan berpengaruh positif pada kinerja perusahaan. Hal ini menunjukkan bahwa semakin besar proporsi opsi saham dalam ESOP yang dihibahkan kepada karyawan maka kinerja perusahaan juga akan semakin meningkat.

Hipotesis kedua $\left(\mathrm{H}_{2}\right)$ dalam penelitian ini menyatakan bahwa kinerja perusahaan berpengaruh positif pada nilai perusahaan. Berdasarkan hasil analisis jalur yang telah ditunjukkan pada Tabel 3. menunjukkan bahwa koefisien regresi standar sebesar 0.332 dengan tingkat signifikansi sebesar 0.029 lebih kecil dari 0.05. Hasil ini berarti $\mathrm{H}_{0}$ ditolak dan $\mathrm{H}_{2}$ diterima, sehingga dapat disimpulkan bahwa kinerja perusahaan berpengaruh positif pada nilai 
perusahaan. Hal ini menunjukkan bahwa semakin tinggi kinerja perusahaan maka nilai perusahaan juga akan semakin meningkat.

Hipotesis ketiga $\left(\mathrm{H}_{3}\right)$ dalam penelitian ini menyatakan bahwa jumlah opsi saham yang dihibahkan berpengaruh positif pada nilai perusahaan. Berdasarkan hasil analisis jalur yang telah ditunjukkan pada Tabel 3. menunjukkan bahwa koefisien regresi standar sebesar 0.422 dengan tingkat signifikansi sebesar 0.010 lebih kecil dari 0.05. Hasil ini berarti $\mathrm{H}_{0}$ ditolak dan $\mathrm{H}_{3}$ diterima, sehingga dapat disimpulkan bahwa jumlah opsi saham yang dihibahkan berpengaruh positif pada nilai perusahaan.

Hipotesis keempat $\left(\mathrm{H}_{4}\right)$ dalam penelitian ini menyatakan bahwa kinerja perusahaan memediasi berpengaruh jumlah opsi saham yang dihibahkan terhadap nilai perusahaan. Berdasarkan hasil penelitian analisis jalur menunjukkan bahwa jumlah opsi saham yang dihibahkan secara langsung berpengaruh positif signifikan terhadap kinerja perusahaan. Jumlah opsi saham yang dihibahkan juga berpengaruh positif dan signifikan pada nilai perusahaan. Berdasarkan metode pemeriksaan diperoleh bahwa kinerja perusahaan merupakan variabel mediasi sebagian dan begitu pula hasil perhitungan Uji Sobel diperoleh nilai $\mathrm{Z}$ hitung sebesar 2,0585 > 1,96 yang menunjukkan bahwa kinerja perusahaan merupakan variabel mediasi. Hasil tersebut menunjukkan bahwa $\mathrm{H}_{4}$ diterima dan $\mathrm{H}_{0}$ ditolak yang berarti kinerja perusahaan merupakan variabel yang memediasi pengaruh jumlah opsi saham yang dihibahkan pada nilai perusahaan atau dengan kata lain jumlah opsi saham yang dihibahkan berpengaruh secara tidak langsung pada nilai perusahaan melalui kinerja perusahaan. Semakin besar jumlah opsi saham yang dihibahkan, maka akan menyebabkan tingginya kinerja perusahaan sehingga nilai perusahaan juga akan meningkat.

\section{SIMPULAN}

Simpulan penelitian ini yaitu jumlah opsi saham yang dihibahkan berpengaruh positif pada kinerja perusahaan karna timbulnya sense of belonging karyawan. Kinerja perusahaan berpengaruh positif pada nilai perusahaan karena perolehan laba (profit) yang menarik investor untuk menanamkan modalnya pada perusahaan, sehingga nilai perusahaan tersebut akan meningkat. Jumlah opsi saham yang dihibahkan berpengaruh positif pada nilai perusahaan. Hal ini berarti pelaksanaan ESOP dipandang oleh investor sebagai faktor yang mampu meningkatkan nilai perusahaan. Jumlah opsi saham yang dihibahkan berpengaruh pada nilai perusahaan secara tidak langsung melalui kinerja perusahaan. Insentif berupa hibah opsi saham dalam pelaksanaan ESOP diharapkan dapat meningkatkan nilai perusahaan melalui peningkatan kinerja perusahaan.

Saran yang dapat dikemukakan yaitu perusahaan di Indonesia dengan karyawan yang memenuhi persyaratan diharapkan menerapkan program ESOP ini agar memotivasi karyawan untuk meningkatkan kinerjanya. Investor dapat menjadikan program ESOP sebagai pertimbangan dalam keputusan berinvestasi pada suatu perusahaan. 


\section{REFERENSI}

Apsari, I. A. (2015). Pengaruh Return On Equity, Net Profit Margin, Debt To Equity Ratio, dan Longterm Debt To Equity Ratio Terhadap Price Book Value (Studi Pada Perusahaan Sub Sektor Makanan dan Minuman yang Terdaftar di Bursa Efek Indonesia Periode Tahun 2010-2013). Jurnal Administrasi Bisnis, 27(2), 1-8.

Aribawa, D. (2016). Analisis Nilai Perusahaan pada Implementasi Program Kepemilikan Saham pada Karyawan/Manajemen. Jurnal Ekonomi Dan Bisnis, 19(3), 341-353.

Astika, I. B. P. (2012). Harga Referensi dan Return Expectation dalam Employee Stock of Option Plan. Jurnal Keuangan Dan Perbankan, 14(1), 89-99.।

Bacha, O. I., Raihan, S., Rasid, M., \& Mohd, A. (2009). Granting Employee Stock Options (ESOs), Market Reaction and Financial Performance. Asian Academy of Management Journal of Accounting and Finance, 5(1), 117- 138.

Bapepam. (2002). Studi tentang Penerapan ESOP Perusahaan Publik di Pasar Modal Indonesia. Departemen Keuangan Republik Indonesia.

Blasi, J., Freeman, R., \& Kruse, D. (2016). Do Broad-based Employee Ownership , Profit Sharing and Stock Options Help the Best Firms Do Even Better? British Journal OfIndustrial Relations, 54(1), 55-82. https://doi.org/10.1111/bjir.12135

Dharmala, N. W. D. (2019). Pengaruh Pemberian Employee Stock Option Plan (ESOP) pada Kinerja Perusahaan dan Implikasinya Terhadap Nilai Perusahaan. E-Jurnal Akuntansi Universitas Udayana, 26(3), 1796-1825.

Fama, E. F. (1978). The Effect of a Firm Investment and Financing Decisison on the Welfare of its Security Holders. American Economic Review, 68, 271-282.

Fang, Honghyan, John R. Nofsinger, and Juan Quan. (2014). The Effects of Employee Stock Option Plans on Operating Performance in Chinese Firms. Journal of Banking $\mathcal{E}$ Finance, 1-56.

Han, T. S., \& Shen, C. H. (2007). The effects of bonus systems on firm performance in Taiwan's high-tech sector. Journal of Comparative Economics, 35(1), 235-249.

Haqqi, L. A. H. Q. Al, Cholifah, \& Istanti, E. (2017). Analisis Pengaruh ROA, ROE, NPM Terhadap Nilai Perusahaan Pada PT. Garuda Indonesia (PERSERO) Tbk. E-Jurnal Ekonomi Bisnis Universitas Bhayangkara Surabaya, $3(2), 11-23$.

Herdinata, C. (2012). Reaksi Pasar terhadap Pengumuman Employee Stock Ownership Program. Jurnal Keuangan Dan Perbankan, 16(1), 77-85.

Hutnaleontina, P. N. (2016). Pengaruh Penerapan Employee Stock Optional Plan pada Nilai Perusahaan dengan Kinerja Keuangan sebagai Variabel Intervening. E-Jurnal Akuntansi Universitas Udayana, 5(6), 1757-1784.

Iqbal, Z., \& Hamid, S. A. (2000). Stock Price and Operating Performance of ESOP Firms: A Time-Series Analysis. Quarterly Journal of Business and Economics, 39(3), 25-47.

Jensen, M., \& Meckling, W. (1976). Theory of the Firm: Managerial Behavior, Agency Costs, and Ownership Structure. Journal of Financial Economics, 3(4), 305-360. 
Kalra, N., \& Bagga, R. (2017). A Review of Employee Stock Option Plans : Panacea or Pandora 's Box for Firm Performance. International Journal of Management Excellence, 10(1), 1201-1207.

Letlora, S. C. (2012). Pengaruh Pengumuman Employee Stock Option Program Terhadap Reaksi Pasar dan Kinerja Perusahaan Pada Perusahaan Publik yang Terdaftar di Bursa Efek Indonesia. Journal of Business and Banking, 2(2), 227-240.

Mardiantari, N. P. E. (2015). Kinerja Keuangan Perusahaan di Sekitar Peristiwa Pengumuman Esop dan Pengaruhnya pada Nilai Perusahaan. E-Jurnal Akuntansi Universitas Udayana, 13(2), 532-548.

Murhadi, W. R. (2009). Analisis Saham Pendekatan Fundamental. Jakarta: PT Indeks. Ngambi, M. T., \& Oloume, F. (2013). Employee Share Ownership and Firm Performance: Evidance From A Sample of Cameroonian Firms. International Journal of Research in Social Sciences, 2(3), 48-55.

Poornima, D. ., Kala, K. N., \& Kala, D. . V. (2015). Impact of Employee Stock Options on Corporate Performance with Special Reference to Selected Financial Services Companies in India. Journal of Research in Management, Social Sciences and Technology, 9(9), 1-5.

Pugh, W. N., Oswald, S. L., \& Jahera, J. S. (2000). The effect of ESOP adoptions on corporate performance: are there really performance changes? Journal of Managerial and Decision Economics, 21(5), 167-180.

Qureyta, H. D. (2016). Pengaruh Kebijakan Employee Stock Ownership Program terhadap Perkembangan Kinerja Keuangan dan Kinerja Pasar Perusahaan yang Terdaftar di Bursa Efek Indonesia. STIE Perbanas Surabaya, 1-17.

Rathore, M. R., \& Shukla, R. K. (2015). Do ESOP Enhance Productivity Performance in Pharmaceutical Sector?: A Study of selected Pharmaceutical Companies. IFRSA Business Review, 5(1), 14-22.

Ricci, T. N. (2018). Pengaruh Employee Stock Option Plan pada Kinerja Perusahaan dan Implikasinya pada Return Saham. E-Jurnal Akuntansi Universitas Udayana, 22(2), 831-855.

Scott, B., \& Brigham, E. F. (2008). Essential of Managerial Finance (14th ed). Ontario: Prentice Hall Canada Inc.

Setiawan, N. H. (2017). Perbedaan Kinerja Keuangan dan Kinerja Pasar Sebelum dan Setelah Penerapan ESOP pada Perusahaan yang Tercatat di BEI. STIE Perbanas Surabaya, 1-13.

Wahyu, D. D., \& Mahfud, M. K. (2018). Analisis Pengaruh Net Profit Margin, Return On Assets, Total Assets Turnover, Earning Per Share, dan Debt To Equity Ratio Terhadap Nilai Perusahaan (Studi Pada: Perusahaan Manufaktur yang terdaftar di Bursa Efek Indonesia Periode 2010-2016). Diponegoro Journal Of Management, 7(2), 1-11.

Watts, R. L., \& J. L., Zimmerman. (1986). Positive Accounting Theory. New Jersey: Prentice-Hall International Inc.

Zhu, Z., Hoffmire, J., Hoffmire, J., \& Wang, F. (2013). Employee Stock Ownership Plans and Their Effect on Productivity: The Case of Huawei. International Journal of Business and Management Invention, 2(8), 17-22. 